Ambiente \& Água - An Interdisciplinary Journal of Applied Science
ISSN 1980-993X - doi:10.4136/1980-993X
www.ambi-agua.net
E-mail: ambi-agua@agro.unitau.br

\title{
Induction of cytotoxic and genotoxic effects of Guandu River waters in the Allium cepa system
}

\author{
doi: 10.4136/ambi-agua.1487
}

Received: 15 Aug. 2014; Accepted: 23 Oct. 2014

\author{
Jennifer Vieira Gomes; Jéssica Tamara dos Santos Teixeira; \\ Viviane Moreira de Lima*; Helcio Resende Borba \\ Universidade Federal Rural do Rio de Janeiro, Seropédica, RJ, Brasil \\ Instituto de Biologia, Departamento de Biologia Animal \\ *Corresponding author: e-mail: vilima@ hotmail.com, \\ vieira.jb@hotmail.com, jteixeira2911@gmail.com, borba@ufrrj.br
}

\begin{abstract}
The Guandu River is the main source of water supply for the metropolitan region of Rio de Janeiro and has been facing serious environmental problems due to increasing population and industrial pollution, as well as the presence of polluted tributaries. This study analyzed the cytotoxic and genotoxic potential of the Guandu River's waters, through the use of the Allium cepa test system. Collection points were chosen at the greatest confluences of pollutant sources. The sampling included two different seasons: the rainy season (January and February) and the dry season (June and July). The analyses of 5000 cells per treatment showed that all the points studied had some degree of cytotoxicity and/or genotoxicity. Two sampling locations, which receive major influxes from the polluted waters of the Poços/Queimados and Cabuçu/Ipiranga Rivers, stood out for the strong presence of micronuclei, sticky chromosomes, mitotic spindle abnormalities, necrotic cells and nucleolar changes compared to the negative control. At least two locations also found changes in the mitotic index. The existence of variations in the number of cytotoxic and genotoxic changes between periods of rain and drought indicates that the cytotoxic and genotoxic potential of the water pollutants varies according to time, depending on the discharges of the tributary rivers and the increase of contaminated effluents. The results highlight the importance of bio-monitoring to assist managers in the control of effluent discharge.
\end{abstract}

Keywords: Allium cepa, cytotoxicity, genotoxicity.

\section{Indução de efeito citotóxico e genotóxico das águas do Rio Guandu em sistema Allium cepa}

\section{RESUMO}

O Rio Guandu é a principal fonte de água para abastecimento da região metropolitana do Rio de Janeiro e enfrenta sérios problemas ambientais devido à crescente poluição tanto de origem populacional quanto industrial acentuada pela presença de afluentes com águas poluídas. Este trabalho teve por objetivo analisar o potencial citotóxico e genotóxico das águas do Rio Guandu, utilizando para isto o sistema teste de Allium cepa. Foram escolhidos pontos de coleta nos quais ocorrem as maiores confluências de fontes poluidoras. As coletas 
foram realizadas em duas épocas distintas: na estação chuvosa (Janeiro e Fevereiro) e na estação de estiagem (Junho e Julho). As análises realizadas em 5000 células por tratamento demonstraram que todos os pontos estudados apresentaram algum nível de citotoxicidade e ou genotoxicidade. Dois locais de coleta, os quais recebem maiores influências das águas poluídas dos rios Poços/Queimados e Cabuçu/Ipiranga, se destacaram quanto à presença acentuada de micronúcleos, aderência cromossômica, anormalidades no fuso mitótico, células em necrose e alterações nucleolares em relação ao controle negativo. Foram encontradas também alterações no índice mitótico em pelo menos dois locais. A existência de variações no número de alterações citotóxicas e genotóxicas entre os períodos chuvosos e de seca indicam que o potencial citotóxico e ou genotóxico dos poluentes na água variam em função do tempo, dependendo das descargas vindas dos afluentes e do aumento na emissão de efluentes contaminados. Estes resultados ressaltam a importância de estudos de biomonitoramento que auxiliem as ações de manejo visando o controle do lançamento de efluentes.

Palavras-chave: Allium cepa, citotoxicidade, genotoxicidade.

\section{INTRODUCTION}

The Guandu River is the main source of water supply for the Rio de Janeiro metropolitan region. The Guandu River Basin, located west of the Guanabara Bay, covers an area of $3.600 \mathrm{~km}^{2}$, including 15 municipalities, and is the only water source for subsistence and for the development of the metropolitan region of the state (Bruno, 2012). Guandu River is $48 \mathrm{~km}$ long, and formed by the joining of the Santana and Ribeirão das Lages Rivers; it discharges into Sepetiba Bay. Much of its water comes from the Rio Paraiba do Sul, through a transposition that occurs in the municipality of Barra do Pirai (Salamene, 2007).

Despite its importance, the Guandu River faces serious environmental problems due to unplanned urban development in the municipalities of the Guandu Basin, the release of domestic and industrial effluents, illegal solid waste disposal and illegal sand extraction. This pollution is further enhanced by the joining of Guandu River with the Poços/Queimados and the Cabuçu/Ipiranga Rivers, the waters of which are very polluted. This joining occurs in the Guandu Lagoon, which is formed by CEDAE dams, and which is connected to the Guandu River and has low rate of water renewal due to its configuration (Serber, 2005; Salamene, 2007). In addition, the Paraíba do Sul River, the main water contributor to the Guandu River, is polluted with domestic and industrial untreated effluents as well as agricultural waste (Oliveira et al., 2011). All of these factors affect the quality of the water that is treated at the Guandu Water Treatment Station (WTS). There are also several quality of life issues. For example, industrial, agricultural and urban residues contain organic and inorganic compounds that often are not degraded during the water treatment process, and some of these are genotoxic (Nielsen and Rank, 1994; Oliveira et al., 2011). Also, the increasing reduction of water quality may in the near future render it very difficult to treat (Serber, 2005). The Allium cepa test system is used as a bioindicator in studies evaluating environmental genotoxic potential (Barbério et al., 2009; Leme and Marin-Morales, 2009) and was validated by the International Programme of Chemical Safety (IPCS, WHO) and the United Nations Environment Programme (UNEP) as an effective test for analysis and in situ monitoring of the cytotoxicity and genotoxicity of environmental substances (Bagatini et al., 2007), as indicated by several authors (Nielsen and Rank, 1994; Grover and Kaur, 1999; Leme and Marin-Morales, 2008; Hoshina and Marin-Morales, 2009; Barbério et al., 2009; Barbosa et al., 2010; Radic et al., 2010; Oliveira et al., 2011).

This study analyzed the water of Guandu River at specific locations during the dry and rainy seasons in order to evaluate cytotoxic and genotoxic effects. 


\section{MATERIAL AND METHODS}

\subsection{Collection sites}

Samples were collected at three locations prior to capitation by the Guandu Water Treatment Station (WTS) and where the Guandu River receives significant influxes of water from polluted tributaries as follows: Local A - the Ipiranga River at the point where it joins the Guandu Lagoon ( $22^{\circ} 48^{\prime} 10.2^{\prime}$ S, $43^{\circ} 37^{\prime} 24.0^{\prime}$ ' O); Local B - the Guandu Lagoon after the joining of the Poços and Ipiranga Rivers (22 $\left.48^{\prime} 20.9^{\prime \prime} \mathrm{S}, 43^{\circ} 37^{\prime} 38.8^{\prime \prime} \mathrm{O}\right)$ and Local $\mathrm{C}$ - the Ribeirão das Lages River following the influx of the Paraíba do Sul River

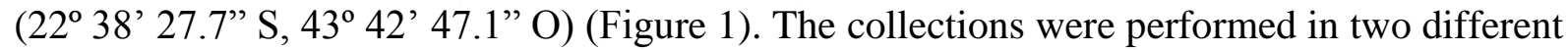
seasons: dry season (June and July 2012) and the rainy season (January and February 2013).
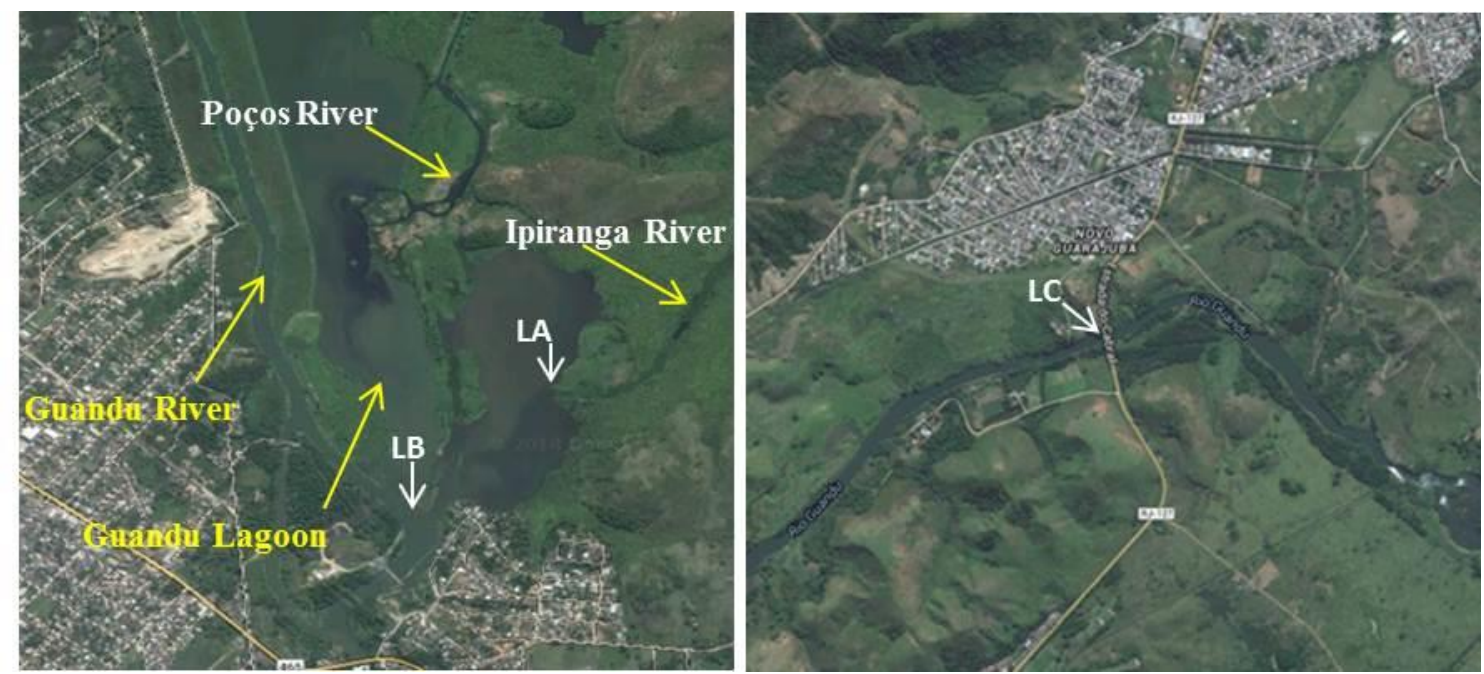

Figure 1. Collection sites - Local A (LA) - the Ipiranga River at the point that it joins the Guandu Lagoon; Local B (LB) - the Guandu Lagoon after the influx of the Poços and Ipiranga Rivers; Local C (LC) - the Ribeirão das Lages River after the influx of the Paraíba do Sul River.

\subsection{Sample collection}

Samples from each site were collected with the aid of a $10 \mathrm{~L}$ bucket and transferred to polyethylene flasks ( $1 \mathrm{~L})$ that were properly identified and kept in coolers with ice for transport to the laboratory, where they were kept under refrigeration $\left(4^{\circ} \mathrm{C}\right)$ for further genotoxicity and cytotoxicity analysis.

\subsection{Cytotoxicity and genotoxicity tests}

Commercially acquired organic cultured onion bulbs approximately $2.0 \mathrm{~cm}$ in diameter were used to test performance. A stylet was used to remove external catafilo from each bulb without damaging the root buds. Five onion bulbs were used for water samples from each locale, as well as positive and negative controls. Initially, the bulbs were placed into a container with distilled water for 48 hours, with daily water exchanges. The bulbs were then transferred to tubes containing water samples collected at the locales previously mentioned, where they remained for 48 hours. The bulbs used as negative controls were kept in distilled water and the positive ones were placed in an ethylmethane sulfonate (EMS, $25 \mathrm{mM}$ ) solution. The tests and the control bulbs were incubated at $25^{\circ} \mathrm{C}$ with daily water exchanges. For each treatment, 2 and $2.5 \mathrm{~cm}$ roots apical meristems were removed from the bulbs after 48 hours of exposure to the solution and were processed according Iganci et al. (2006) for slide preparation with some modifications. Meristems were fixed on ethanol: glacial acetic acid solution in a 3:1 ratio (V/V) and stored at $4^{\circ} \mathrm{C}$ until slide preparation. Five meristems 
were used to prepare five slides for each bulb. For slide performance, meristems were twice washed in distilled water for $5 \mathrm{~min}$, hydrolyzed with $5 \mathrm{~N} \mathrm{HCl}$ for $30 \mathrm{~min}$, then again twice washed in distilled water for $5 \mathrm{~min}$ and stained with $2 \%$ acetic orcein. Meristems regions were fragmented with a scalpel blade and the coverslip was placed and pressed over the material. Slides were observed on a 100X optical microscope. The presence of cellular and chromosomal abnormalities was analyzed at 1000 cells/bulb for a total of 5000 cell treatment.

\subsection{Analysis of the potential for the induction of cell death}

Onion roots submitted to various treatments, as described above, were analyzed for the ability to induce cell death using propidium iodide and the 33342 Hoescht staining technique (Locke et al., 1990). Longitudinal cuts were made in the roots' meristematic regions. A drop of Hoescht $\left(10 \mu \mathrm{g} \mathrm{mL}^{-1}\right)$ dye was added to each slide for the staining technique. After $10 \mathrm{~min}$, the material was transferred to another slide and submitted to a drop of propidium iodide $\left(30 \mu \mathrm{g} \mathrm{mL} \mathrm{m}^{-1}\right)$. Both incubations were protected from light. As a positive control, roots submitted to fixing (ethanol: glacial acetic acid on 3:1 ratio) were used, since fixing promotes cell death. Subsequently, the material was analyzed, evaluated and photographed by a fluorescence microscope (Zeiss Axid Lab A1) under $365 \mathrm{~nm}$ and $400 \mathrm{~nm}$ excitation filters. According to Locke et al. (1990) 33342 Hoescht stains intact membrane cells while propidium iodide stains only the compromised ones. The nuclei with fluorescent blue cells were considered alive and intact, while those with fluorescent red nuclei were considered not intact, in a process of cell death.

\subsection{Statistical design}

Statistical analyses of data obtained through the Allium cepa test for the assessment of cytotoxicity and genotoxicity of the water samples were evaluated by the $\chi^{2}$ test, using the Yates correction, with Bioestat 5.0 software.

\section{RESULTS AND DISCUSSION}

The principal use of the Guandu River waters is for the intake of drinking water for treatment. Water treated at the WTS (Water Treatment Station) has served $80 \%$ of the metropolitan region of Rio de Janeiro's population. However, for this treatment be effective, it is necessary that the so-called "raw water" does not reach certain levels of pollution (Oliveira et al., 2011).

\subsection{Cytotoxicity and genotoxicity}

Analysis showed the presence of micronuclei, chromosomal fragment loss, chromosomal bridges, sticky chromosomes and abnormalities in mitotic spindle, including in this group cells with c-metaphase, polyploide metaphase, irregular metaphase, multipolar anaphase, delayed anaphase, vagrant chromosome of the chromatinic group and binucleated cells. Necrotic cells and nucleolar changes, with the presence of large nucleoli cells, were also observed, this being one of the representative changes from the positive control (Figure 2).

During the dry season (June and July), at Locale B at the Guandu Lagoon, the mixture formed after the confluence of the Poços/Queimados and Ipiranga Rivers presented a higher number of necrotic and micronucleated cells in relation to the negative control (Table 1), which is indicative of the presence of pollutants with cytotoxic and genotoxic potential. Micronuclei are formed in dividing cells presenting acentric chromosome fragments and/or whole chromosomes that disrupted the ability to bind to mitotic spindle, indicating the presence of substances with clastogenic and aneugenic effects (Fenech, 2000). The locale where the Ipiranga River joins with the Guandu Lagoon (Locale A) presented a significant number of cells with nucleolar changes when compared to the negative control (Table 1). 

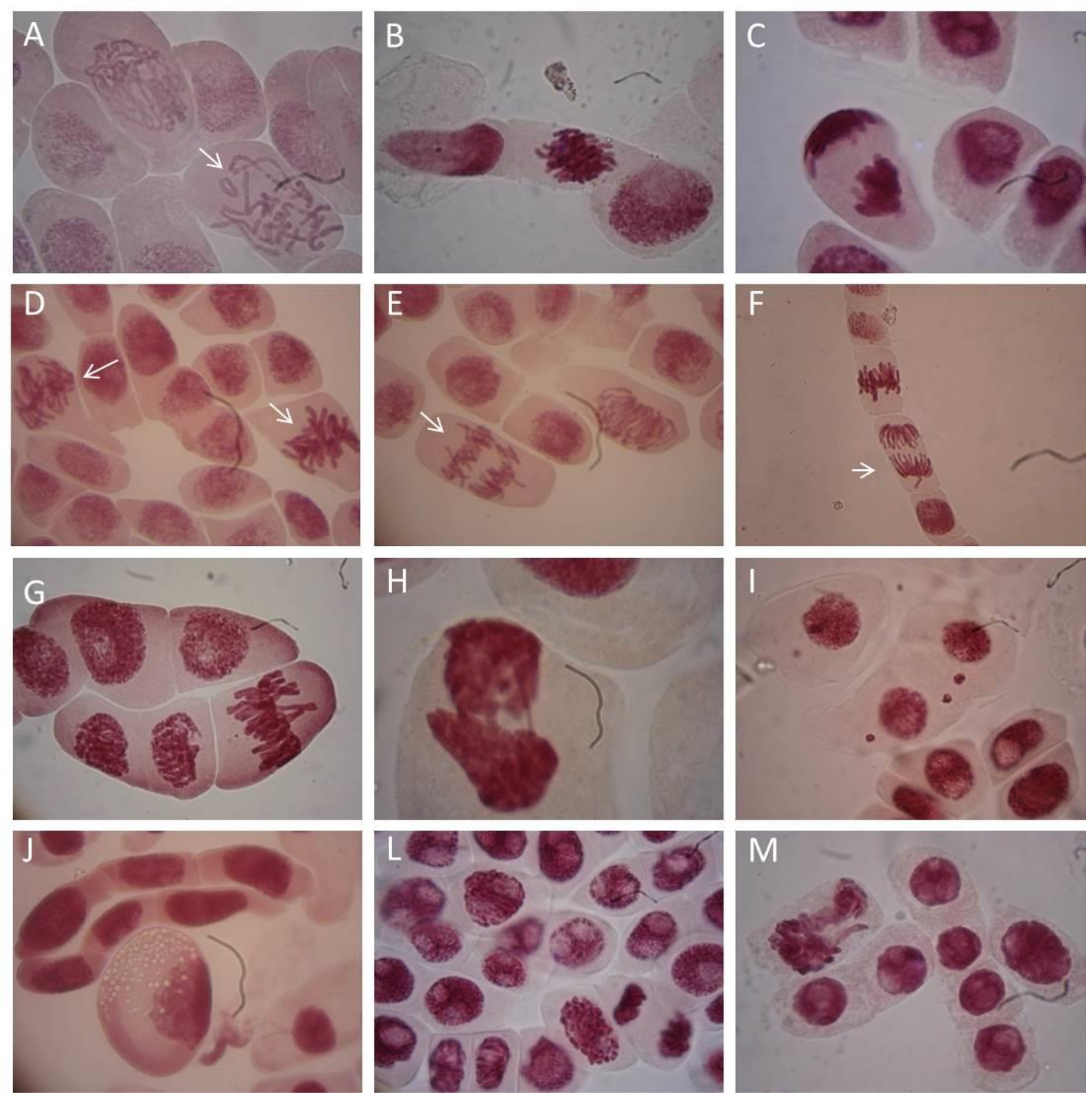

Figure 2. Allium cepa meristematic cells exposed to ethyl methane sulfonate (EMS) (M) and water samples collected at different sites (A-L); (A) c-metaphases (arrow); (B-C) sticky chromosomes; (D-E) spindle abnormalities (arrow); (F) vagrant chromosome (arrow); (G) irregular metaphase; (H) chromosomal bridge; (I) micronucleated cells; (J) necrotic cells; (L-M) nucleolar changes.

Nucleolar changes are characteristic in cells treated with the positive control EMS employed in the present survey. EMS is a highly efficient mutagenic agent directly acting on the DNA molecule through its alkylating activity. These sort of changes are the most common criteria used as an indication of malignancy, differentiating normal cells from the malignant ones with the malignant cells nuclei presenting a variable nucleoli number of different sizes and shapes (Oshima and Forones, 2001; Filippin et al., 2006; Montanaro et al., 2008). Locale C, the Ribeirão das Lages River following the influx of the Paraíba do Sul River showed no significant changes (Table 1).

During the rainy season (January and February), the sample that stood out with significant changes was Locale A, which showed a higher number of cells with chromosomal abnormalities in the mitotic spindle and sticky chromosomes compared to the negative control (Table 2). Sticky chromosomes are characterized by chromatic clustering involving few chromosomes or the whole genome, possibly resulting in chromatin degeneration and cell death. Thus, detection of such abnormalities has indicated the presence of toxic substances at 
this site. Locale $\mathrm{C}$ presented a greater number of nucleolar changes (Table 2). In this season, water samples collected at Locale B showed no significant changes when compared to the negative control (Table 2). This result was probably influenced by a high rainfall level during the collection time, since Locale B (the Guandu Lagoon) is formed by the confluence of the Guandu River with the Poços/Queimados and Ipiranga Rivers and thus, depending on the collection site, a greater influence of the Guandu River's waters might be possible, where pollution indicators are lower than those of the Guandu Lagoon's tributaries (Coelho et al., 2012).

Table 1. Cells changes and mitotic index in A. cepa roots submitted to different treatments during the dry season.

\begin{tabular}{llccccc}
\hline Treatment & Concentration & LN & LNB & NEC & MC & ID (\%) \\
\hline Negative control & Distilled water & $163^{(\mathrm{b})}$ & $1^{(\mathrm{b})}$ & 13 & 7 & 6.7 \\
EMS & $25 \mathrm{mM}$ & $1224^{(\mathrm{a})}$ & $169^{(\mathrm{a})}$ & $58^{(\mathrm{a})}$ & 7 & 4.5 \\
Local A & & $\mathbf{2 7 2}^{(\mathrm{a})}$ & 2 & 19 & 8 & 7.7 \\
Local B & & 183 & $\mathbf{9}^{(\mathrm{a})}$ & $\mathbf{3 0}^{(\mathrm{a})}$ & $\mathbf{2 0}^{\text {(b)(a) }}$ & 5.9 \\
Local C & & $95^{(\mathrm{a})(\mathrm{b})}$ & $0^{(\mathrm{b})}$ & 12 & 2 & $\mathbf{1 0 . 4}$ \\
\hline
\end{tabular}

Note: ${ }^{(a)}$ Significant difference compared to negative control $(\mathrm{P}<0,05)$ according to the $\chi^{2}$ test;

(b) Significant difference compared to positive control $(\mathrm{P}<0,05)$ according to the $\chi^{2}$ test; $\mathbf{L N}$ - one or more large nucleoli; LNB - one or more large nucleoli and nuclear bud; NEC - necrotic cells; MC - micronucleated cells; ID - mitotic index. 5000 cells for each treatment were analyzed.

Mitotic index analysis of the onions' meristematic cells submitted to different water samples in the dry and rainy seasons was also employed for cytotoxicity evaluation. In both seasons, Locale $\mathrm{C}$ presented a significantly greater mitotic index than that observed in the negative control (Table 1 and Table 2). However, Locale A presented a significantly greater mitotic index than that observed in the negative control, in the rainy season only (Table 2). No significative changes were reported in regard to the mitotic index for Locale B.

Table 2. Cells changes and mitotic index in A. cepa roots submitted to diferent treatments during the rainy season.

\begin{tabular}{llllllc}
\hline Treatment & Concentration & LN & LNB & SA & SC & ID (\%) \\
\hline Negative control & Distilled water & $229^{(\text {b) }}$ & $4^{(\mathrm{b})}$ & 8 & 2 & 2.3 \\
EMS & $25 \mathrm{mM}$ & $572^{(\mathrm{a})}$ & $27^{(\mathrm{a})}$ & 13 & 8 & 3.4 \\
Local A & & 198 & 13 & $\mathbf{2 9}^{(\text {a) }}$ & $\mathbf{1 3}^{(\mathrm{a})}$ & $\mathbf{4 . 3}$ \\
Local B & & 183 & 3 & 11 & 6 & 2.8 \\
Local C & & $\mathbf{3 0 0}^{(\mathrm{a})}$ & 9 & 14 & 8 & $\mathbf{5 . 5}$ \\
\hline
\end{tabular}

Note: ${ }^{\text {(a) }}$ Significant difference compared to negative control $(\mathrm{P}<0,05)$ according to $\chi^{2}$ test; (b) Significant difference compared to positive control $(\mathrm{P}<0,05)$ according to $\chi^{2}$ test; $\mathbf{L} \mathbf{N}$ - one or more large nucleoli; LNB - one or more large nucleoli and nuclear bud; SA - spindle abnormalities; SC - sticky chromosomes; ID - mitotic index. 5000 cells for each treatment were analyzed.

The increase or decrease of the mitotic index might be a relevant indicator for monitoring pollution levels of contaminated environments, especially those contaminated by potentially toxic and cytotoxic compounds (Fernandes et al., 2007; Caritá and Marin-Morales, 2008). 
Greater mitotic indices than those reported in the negative control are from the induction of increased cell division, which characterizes cell damage, producing uncontrolled proliferation and eventually causing further tumor development. Smaller mitotic indices than those in the negative control might indicate that the growth and development of organisms is being affected by components in the samples (Hoshina, 2002; Caritá and Marin-Morales, 2008).

Despite the alterations induced by the water samples from Locale B during the dry season, it no changes were observed in the mitotic index. This is because the cytotoxic agents are able to act on the cell in a broad manner, acting on its compartments, the organization of its components and can thus cause morphological, biochemical and physiological changes that can affect the cell cycle or induce death cell (Kaioumova et al., 2001; Costa and Huck, 2006; Capobiango et al., 2009). These changes may also lead indirectly to changes in the genetic material; however, a cytotoxic effect is not necessarily associated with a genotoxic effect (Oliveira et al., 2011), which also explains the fact that no genotoxic changes were detected in the meristematic cells treated with the water sample from the Locale $\mathrm{C}$ during the dry season, although there was a change in the mitotic index.

\subsection{Induction test for cell death}

Considering that water collected from Locale B during the dry period presented a significant number of necrotic cells when compared to the negative control (Table 1), the presence of components which induce cell death was confirmed through the 3342 Hoescht and propidium iodide dyes. Both dyes presented a specific staining, clearly observed by the colors red (for dead cells) and green/blue (for live cells) (Collins and Donoghue, 1999). In this analysis, Locale B presented more extensive cell death when compared to the negative control (Figure 3).
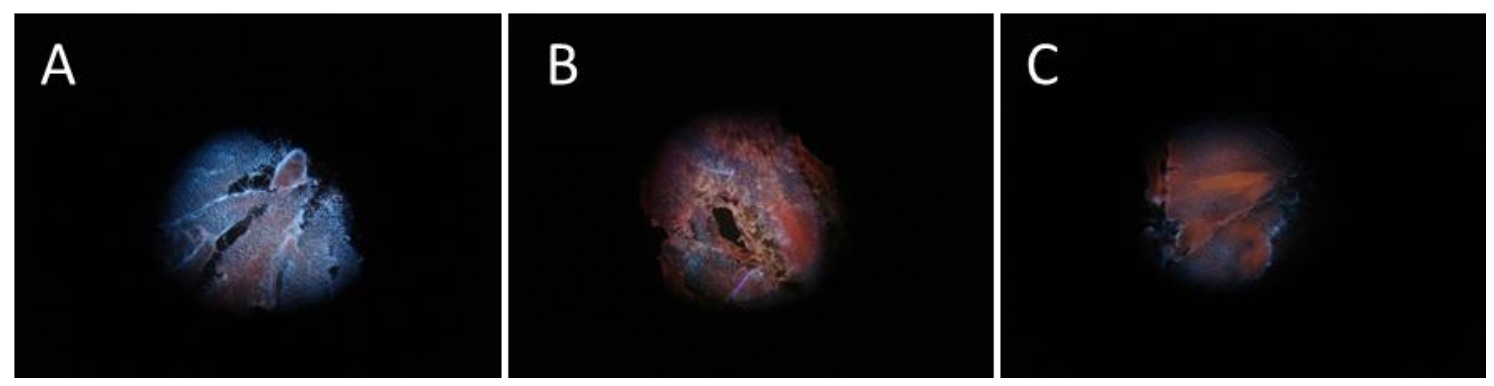

Figure 3. Allium cepa meristematic cells submitted to different treatments: (A) negative control; (B) fixed cells (positive control); (C) cells exposed to water collected in drought period from Locale B.

Necrosis is not determined by factor intrinsic to cells, but by environmental disturbances, indicating toxic chemicals or toxins promoting cells lysis (Hoshina and Marin-Morales, 2009).

Variations in the number of cytotoxic and genotoxic changes between both seasons, such as those observed on this survey, have also been described by other authors regarding river water from other Brazilian locations (Caritá and Marin-Morales, 2008; Oliveira et al., 2011; Monteiro et al., 2014). Cytotoxic and genotoxic water pollutant potentials have ranged in accordance with time, depending on the discharges of the tributary rivers, as well as increases in the emissions of contaminated effluents. Moreover, high rainfall in summer might promote significant increases in organic matter and toxic compounds discharged into rivers, causing increased cytoxicity and genotoxicity during this season (Monteiro et al., 2014).

The results obtained in this study reflect the level of pollution and indicate the presence of pollutants with cytotoxic and genotoxic effects in the waters of the analyzed locales. 
The Poços, Queimados and Ipiranga Rivers have water of rather dubious quality. The Queimados River receives, untreated, the entire sewage from the urban area of Queimados city, in addition to the effluents generated by industrial activities, and flows into the Poços River; while the Ipiranga River receives a significant portion of effluents from the urban areas of Nova Iguaçu and Queimados (Serber, 2005). These tributaries, which flow into the Guandu Lagoon, present poor quality water, with values outside the limits allowed in monitored parameters, including: dissolved oxygen, total phosphorus, nitrate, ammonia nitrogen and biochemical oxygen demand (Weinberg, 2013; INEA, 2014)

Locale C (the Ribeirão das Lajes River following the influx of the Paraiba do Sul River) showed fewer changes compared to locales A and B, which conforms with the report of Coelho et al. (2012), which noted that the values of the indicators of pollution are much higher in the tributaries of the Guandu Lagoon than in the Guandu River upstream of the main dam CEDAE. At this locale, the Guandu River receives a large volume of water from the Paraíba do Sul River, which at this point has already been polluted by domestic and industrial untreated effluents and waste from agricultural sources (Oliveira et al., 2011). However, although this pollution is present, as also indicated by the observed changes in the mitotic index, it may be mitigated to some extent due to the water's transit time sedimentation occurring in the reservoirs of Light in Barra do Piraí, where the confluence occurs.

\section{CONCLUSIONS}

This survey detected the existence of potential cytotoxic and genotoxic in the waters of the analyzed locales. The observed cytotoxic and genotoxic changes reflect the state of contamination of the tributaries and water contributors of the Guandu River, and emphasize the importance of bio-monitoring studies to aid managers in controlling the release of domestic and industrial effluents. These components exhibit potent cytotoxic and/or genotoxic properties, some of which cannot be degraded during the treatment process, and may thus render even treated water unsafe for human use or consumption.

\section{ACKNOWLEDGMENTS}

Committee of the Guandu Basin and Paraíba do Sul River Basin Agency (AGEVAP) for financial support.

\section{REFERENCES}

BAGATINI, M. D.; DA SILVA, A. C. F.; TEDESCO, S. B. Uso do sistema teste de Allium cepa como bioindicador de genotoxicidade de infusões de plantas medicinais. Revista Brasileira de Farmacognosia, Curitiba, v. 17, n. 3, p. 444-447, 2007. http://dx.doi.org/10.1590/S0102-695X2007000300019

BARBÉRIO, A.; BARROS, L.; VOLTOLINI, J. C.; MELLO, M. L. S. Evaluation of the cytotoxic and genotoxic potential of water from the River Paraíba do Sul, in Brazil, with the Allium cepa L. test. Brazilian Journal of Biology, São Carlos, v. 69, n. 3, p. 837842, 2009. http://dx.doi.org/10.1590/S1519-69842009000400010

BARBOSA, J. S.; CABRAL, T. M.; FERREIRA, D. N.; AGNEZ-LIMA, L. F.; DE MEDEIROS, S. R. Genotoxicity assessment in aquatic environment impacted by the presence of heavy metals. Ecotoxicology Environmental Safety, New York, v. 73, p. 320-325, 2010. http://dx.doi.org/10.1016/j.ecoenv.2009.10.008 
BRUNO, A. A. G. Água, fonte de vida. In: COMITÊ GANDU. Bacia hidrográfica dos rios Guandu, da Guarda e Guandu-Mirim: experiências para a gestão dos recursos hídricos. Rio de Janeiro: INEA, 2012. p. 11-15.

CAPOBIANGO, R. A.; VESTENA, S.; BITTENCOURT, A. H. C. Alelopatia de Joanesia princeps Vell. e Casearia sylvestris Sw. Sob espécies cultivadas. Revista Brasileira de Farmacognosia, Curitiba, v. 19, n. 4, p. 924-930, 2009. http://dx.doi.org/10.1590/S0102-695X2009000600023

CARITÁ, R.; MARIN-MORALES, M. A. Induction of chromosome aberrations in the Allium cepa test system caused by the exposure of seeds to industrial effluents contamined with azo dyes. Chemosphere, New York, v. 72, p. 722-725, 2008.

http://dx.doi.org/10.1016/j.chemosphere.2008.03.056

COELHO, F. M.; DE AZEVEDO, J. P. S.; JÚNIOR, I. V. Análise multicritério de propostas para a melhoria da qualidade da água captada para abastecimento da Região Metropolitana oeste do Rio de Janeiro. In: COMITÊ GUANDU. Bacia hidrográfica dos rios Guandu, da Guarda e Guandu-Mirim: experiências para a gestão dos recursos hídricos. Rio de Janeiro: INEA, 2012. p. 61-77.

COLLINS, A. M.; DONOGHUE, A.M. Viability assessment of honey bee Apis mellifera, sperm using dual fluorescent staining. Theriogenology, New York, v. 51, n. 8, p. 15131523, 1999. http://dx.doi.org/10.1016/S0093-691X(99)00094-1

COSTA, C. A. S.; HUCK, C. E. Efeitos citotóxicos e biocompatibilidade de agentes clareadores usados na odontologia. Uma revisão de literatura. Revista Odontológica do Brasil Central, Goiânia, v. 15, n. 39, p. 3-14, 2006.

FENECH, M. The in vitro micronucleus technique. Mutation Research, Amsterdam, v. 455, p. 81-95, 2000. http://dx.doi.org/10.1016/S0027-5107(00)00065-8

FERNANDES, T. C. C.; MAZZEO, D. E. C.; MARIN-MORALES, M. A. Mechanism of micronuclei formation in polyploidizated cells of Allium cepa exposed to trifluralin herbicide. Pesticide Biochemistry and Physiology, Massachusetts, v. 88, p. 252-259, 2007. http://dx.doi.org/10.1016/j.pestbp.2006.12.003

FILIPPIN, C.; CHISTOFOLETTI, L. D.; RIBEIRO, M. C. M.; VITURI, C. I. Determinação do número de regiões organizadoras de nucléolo (AgNOR) em lesões do epitélio cervical uterino. Revista Brasileira de Análises Clínicas, Rio de Janeiro, v. 38, n. 3, p. 133-139, 2006.

GROVER, I. S.; KAUR, S. Genotoxicity of wastewater samples from sewage and industrial effluent detected by the Allium root anaphase aberration and micronucleus assays. Mutation Research, Amsterdam, v. 426, p. 183-188, 1999. http://dx.doi.org/10.1016/S0027-5107(99)00065-2

HOSHINA, M. M. Avaliação da possível contaminação das águas do Ribeirão Claro, município de Rio Claro, pertencente à Bacia do Rio Corumbataí, por meio de testes de mutagenicidade em Allium cepa. 2002. 52 f. Monografia (Bacharel e Licenciatura em Ciências Biológicas) - Instituto de Biociências, Universidade Estadual Paulista, Rio Claro, SP. 
HOSHINA, M. M.; MARIN-MORALES, M. A. Micronucleus and chromosome aberrations induced in onion (Allium cepa) by a petroleum refinery effluent and by river water that receives this effluent. Ecotoxicology Environmental Safety, New York, v. 72, p. 20902095, 2009. http://dx.doi.org/10.1016/j.ecoenv.2009.07.002

IGANCI, J. R. V.; BOBROWSKI, V. L.; HEIDEN, G.; STEIN, V. C.; ROCHA, B. H. G. Efeito do extrato aquoso de diferentes espécies de boldo sobre a germinação e índice mitótico de Allium cepa L. Arquivos do Instituto Biológico, São Paulo, vol. 73, n.1, p. 79-82, 2006.

INSTITUTO ESTADUAL DO AMBIENTE (Rio de Janeiro). Boletim de qualidade das águas da região hidrográfica II - Guandu, 2014. Disponível em: http://www.inea.rj.gov.br/cs/groups/public/documents/document/zwff/mdi3/ edisp/inea _027650.pdf. Acesso em: 22 set. 2014.

KAIOUMOVA, D.; SÜSAL, C.; OPELZ, G. Induction of apoptosis in Human lymphocytes by the herbicide 2,4-dichlorophenoxyacetic acid. Human Immunology, California, v. 62, p. 64-74, 2001. http://dx.doi.org/10.1016/S0198-8859(00)00229-9

LEME, D. M.; MARIN-MORALES, M. A. Chromosome aberration and micronucleus frequencies in Allium cepa cells exposed to petroleum polluted water-a case study. Mutation Research, Amsterdam, v. 650, p. 80-86, 2008.

http://dx.doi.org/10.1016/j.mrgentox.2007.10.006

LEME, D. M.; MARIN-MORALES, M. A. Allium cepa test in environmental monitoring: a review on its application. Mutation Research, Amsterdam, v. 682, n. 1, p. 71-81, 2009. 10.1016/j.mrrev.2009.06.002

LOCKE, S. J.; PENG, Y. S.; CROOS, N .L. A supravital staining technique for honeybee spermatozoa. Physiological-Entomology, v. 15, n. 2, p. 187-192, 1990.

http://dx.doi.org/10.1111/j.1365-3032.1990.tb00506.x

MONTANARO, L.; TRERÉ, D.; DERENZINI, M. Nucleolus, ribosomes, and câncer. The Americam Journal of Patology, New York, v. 173, n. 2, p. 301-310, 2008. http://dx.doi.org/10.2353/ajpath.2008.070752

MONTEIRO, R. T. R.; SILVA, G. H., MESSIAS, T. G.; QUEIROZ, S. C. N.; ASSALIN, M. R.; CASSOLI, D. R. et al. Chemical and ecotoxicological assessments of water samples before and after being processed by a water treatment plant. Revista Ambiente \& Água - An interdisciplinary Journal of Applied Science, Taubaté, v. 9, n.1, p. 6-18, 2014. http://dx.doi.org/10.4136/ambi-agua.1292

NIELSEN, M. H.; RANK, J. Screening of toxicity and genotoxicity in waste water by the use of the Allium test. Hereditas, Lund, v. 121, n. 3, p. 249-254, 1994.

http://dx.doi.org/10.1111/j.1601-5223.1994.00249.x

OLIVEIRA, L. M.; VOLTOLINI, J. C.; BARBÉRIO, A. Potencial mutagênico dos poluentes da água do rio Paraíba do Sul em Tremembé, SP, Brasil, utilizando o teste Allium cepa. Revista Ambiente \& Água - An Interdisciplinary Journal of Applied Science, Taubaté, v. 6, n. 1, p. 90-103, 2011. http://dx.doi.org/10.4136/ambi-agua.176

OSHIMA, C. T. F.; FORONES, N. M. AgNOR em câncer gástrico. Arquivos de Gastroenterologia, São Paulo, v. 38, n. 2, p. 89-93, 2001. http://dx.doi.org/10.1590/S0004-28032001000200003 
RADIC, S.; STIPANICEV, D.; VUJCIC, V.; RAJCIC, M. M.; SIRAC, S.; PEVALEKKOZLINA, B. The evaluation of surface and wastewater genotoxicity using the Allium cepa test. Science of Total Environment, New York, v. 408, p. 1228-1233, 2010. http://dx.doi.org/10.1016/j.scitotenv.2009.11.055

SALAMENE, S. Estratificação e caracterização ambiental da área de preservação permanente do Rio Guandu, Rj. 2007. 84f. Dissertação (Mestrado em Ciências Ambientais e Florestais) - Universidade Federal Rural do Rio de Janeiro, Rio de Janeiro, 2007.

SERBER, J. B. Diagnóstico ambiental das atividades do pólo industrial de queimados como subsídio ao termo de ajustamento de conduta na gestão sustentável da bacia hidrográfica do Rio Guandu, RJ. 2005. 111f. Dissertação (Mestrado em Engenharia Ambiental) - Universidade do Estado do Rio de Janeiro, Rio de Janeiro, 2005.

WEINBERG, A. Uso de índices de qualidade de água para a caracterização da bacia hidrográfica do Rio Guandu. 2013. 166f. Projeto de Graduação (Curso de Engenharia Ambiental) - Escola Politécnica da Universidade Federal do Rio de Janeiro, Rio de Janeiro, 2013. 